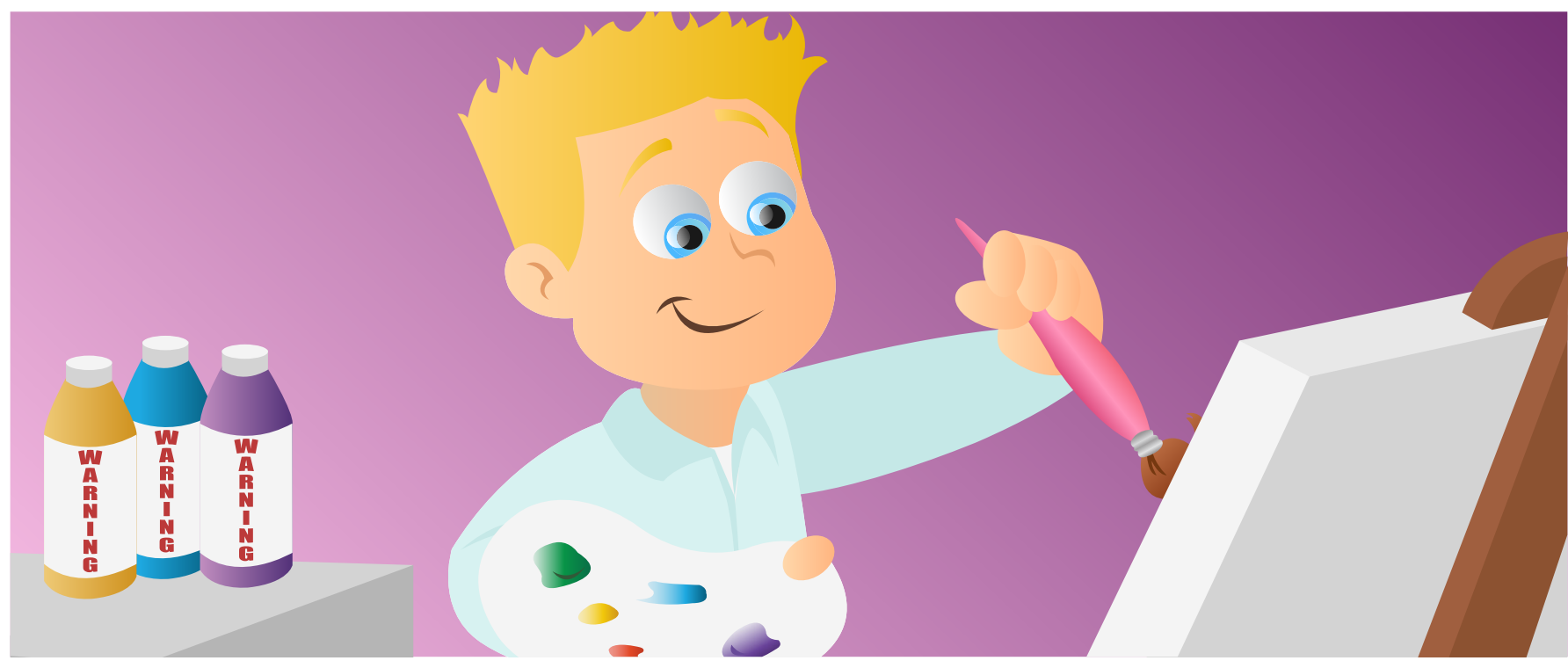

\title{
ART MATERIALS CAN BE DANGEROUS! HOW CAN YOU REDUCE YOUR RISK?
}

\section{Masood A. Shammas ${ }^{1 *}$, Hira Shammas ${ }^{2}$, Samiyah A. Rajput ${ }^{3}$, Dildar Ahmad ${ }^{3}$ and Gulzar Ahmad $^{3}$}

${ }^{1}$ Department of Adult Oncology, Harvard (Dana Farber) Cancer Institute, Boston, MA, USA, ${ }^{2}$ Bur Oak Secondary School, Markham, ON, Canada, 3/nfoTox International Inc., Riverside, CA, USA

\section{REVIEWED BY:}

ALANI

9 YEARS OLD

ALEAH

8 YEARS OLD

MATHEW

"IEARS OLD
Art materials are used by individuals of all ages. Certain chemicals found in art materials have potential to cause health problems, especially if used over a long period of time. The risk can be greater for children, individuals with mental or physical challenges, and people with certain genetic diseases and/or unhealthy lifestyles. However, there are laws and regulations that serve to minimize the risks we take when using these materials. In a recent publication [1], we have proposed that the potential health risks associated with art materials can be further reduced, if the art material labels include the date when the last review of the ingredients was performed. The purpose of this article is to share our findings with younger audiences and raise awareness that: (1) we should make an effort to know the potential health risks associated with art materials we use, especially if we will use them for a long time; (2) we should use these risky materials in a responsible and careful way; and (3) we should always read labels and collect information about the ingredients in art materials and their possible effects on health. 
METALLIC COMPOUNDS

A compound that contains one or more metal elements.

\section{TOXICOLOGIST}

A scientist who studies the adverse effects of drugs, chemicals, and other substances on living organisms.
HOMOLOGOUS RECOMBINATION

A DNA repair system which depends on homology (or similarity) of DNA sequences involved.

\section{INTRODUCTION AND BACKGROUND}

Art has existed in at least some form throughout the history of mankind. Art is widely used as (1) a job, if you're an artist; (2) a tool for teaching; (3) a hobby for people of all ages; (4) an incentive used by parents, day cares, and even restaurants to keep children/individuals entertained and/or busy. These art materials are, therefore, used by a large number of people of all ages. It is important to know that art materials can contain some harmful metallic compounds (chemical substances that contain metals) such as lead, nickel, cadmium, and chromium. Art materials with these chemicals, especially if used carelessly over a long period of time, have the potential to cause cancer and other diseases, including reproductive system disorders.

Every five years, the ingredients of art materials have to be checked or reviewed by an expert, a type of scientist known as a toxicologist. The purpose of this review is to make sure that all the ingredients in each art material are safe, according to the current scientific knowledge. This is important because a product that was considered to be safe 10 years ago may not be considered safe now because of new knowledge that has been discovered during the last 10 years.

\section{WHY DO ART MATERIALS HAVE THE POTENTIAL TO CAUSE HEALTH PROBLEMS?}

Metallic compounds (such as the ones listed in the previous section) and a number of other chemicals can cause damage to the DNA in our body. Our DNA carries the information that guides all the activities being performed in our cells, organs, and bodies. This information is vital and should not be damaged or altered. In a normal cell, if there is any damage to DNA, it is fixed by DNA repair and maintenance systems. However, if a cell or an organ is continuously exposed to a chemical or metallic compound that has ability to damage DNA, then the damage to the DNA becomes excessive. Excessive or continuous damage to DNA is risky because the following things could happen. (1) Some of the damage may be left unrepaired, causing changes in the information carried by the DNA or (2) if this damage occurs in the regions of DNA where repair genes are located, the repair system could become either defective or overactive. Both of these problems can lead to a further increase in the number of changes in the DNA.

It is well known that certain changes in DNA have the potential to turn a normal cell into a cancer cell. More importantly, changes in DNA can also enable a cancer cell to become more aggressive and to resist cancer treatment. Data from our laboratory show that a major DNA repair system known as "homologous recombination" (HR) is overactive in some cancers [2]. Over activation of HR makes it defective and less precise, so instead of just fixing the damaged DNA it also gets involved in making unnecessary rearrangements 


\section{SYNERGISM}

Cooperation of two or more chemicals to produce an effect, which is greater than the sum of their separate effects.

\section{CONSUMER}

PRODUCT SAFETY

COMMISSION

\section{(CPSC)}

An organization of United States government, which ensures that all individuals are protected from the harmful effects of any commercial product they use.

\section{LABELING OF HAZARDOUS ART MATERIALS ACT (LHAMA)}

It is one of the laws (or rule) made by the CPSC. According to LHAMA, the ingredients of all art materials and related products must be checked or reviewed by a toxicologist. This ensures that these products are safe to use.

TOXICOLOGICAL REVIEW

Review of the ingredients of art materials and related products by a toxicologist. of the DNA sequences. We have also found that if you treat cancer cells with nickel that further increases their HR and increases their ability to develop resistance to cancer treatment [2].

Importantly, nickel and some toxic chemicals that have the ability to damage DNA can be harmful even at low doses. This is because the interaction of some of these chemicals with each other or with other things in the environment (for example pesticides, radiation, and viruses) can cause an increase in their harmful impact on DNA. In fact, it has been shown in experiments that the presence of more than one chemical increases their harmful impact [3]. It is known that, in certain cases, the presence of two chemicals together can have more severe effects than the effects of each chemical alone. In toxicology, this phenomenon is called "synergism." Certain genetic diseases or specific lifestyle factors (for example smoking, eating junk food, or eating too much, etc.) [4] have the potential to further increase the risk of such chemicals. In summary, we can say that continuous exposure to art materials containing certain chemicals, especially those with the ability to cause DNA damage, can pose a serious health risk. Some scientific reports actually indicate that the number of deaths caused by cancer is high among people who are artists by profession [5]. Since some of the art materials can have multiple toxic chemicals in them, including chemicals with the ability to damage DNA, the long-term and irresponsible use of these art materials poses a serious health risk. This risk is certainly greater for children and for individuals with mental challenges such as autism.

How are we protected from the harmful chemicals in art materials? A group called the United States Consumer Product Safety Commission (CPSC) ensures that all individuals are protected from the harmful effects of any commercial product they use. One of the laws made by the CPSC is known as the Federal Hazardous Substance Act. One part of this Act is called the Labeling of Hazardous Art Materials Act (LHAMA) [6]. According to LHAMA, the ingredients of all art materials have to be reviewed by a toxicologist, which is called a toxicological review. In this review, the toxicologist has to do the following: (1) use current scientific knowledge to identify any potential health risks associated with any ingredient in the art material; (2) ensure proper labeling of the material to describe potential risks associated with its short- and long-term use. This regulation also requires that art materials be re-reviewed every five years.

\section{HOW CAN THE POTENTIAL HEALTH RISKS OF ART MATERIALS BE REDUCED EVEN MORE?}

\section{BY ASKING THE CPSC TO IMPROVE THE LHAMA REGULATION}

Currently, the users of art materials may not be getting the full benefit from the part of the LHAMA law that requires the ingredients of art materials to 
be checked or reviewed by a toxicologist every five years. This is because the labels on these art materials do not include the expiration date of the toxicological reviews. Therefore, users have no way to find out if the art material they are using is safe according to the current knowledge! We believe that the CPSC should revise the LHAMA and make it necessary for manufacturers to put the expiration dates of the toxicological reviews on art material labels. This will have several benefits: (1) users of art materials will know that these materials have been evaluated using relatively recent scientific knowledge; (2) buyers and sellers will know when to stop selling or buying the product; and (3) people inspecting art materials will know if they are in compliance with the law or not.

\section{BY PROMOTING AWARENESS}

As users of art materials, it is our responsibility to carefully read the labels on these materials and follow instructions. Young people should be taught the importance of reading the labels on art materials and on all other products. To have an idea of how many young people read labels, we conducted a short survey in which 50 students, ranging in age from 14 to 15 years of age, were interviewed. The data are presented in Figure 1. In summary, $80 \%$ of students reported that they use art materials. Of these students, only $30 \%$ answered that they read labels. More importantly, only $12.5 \%$ of students who either knew or had some idea that art materials can contain harmful chemicals reported that they read labels. Although the number of students interviewed is very small, these data do give us some idea that there is a need to inform young people about importance of reading labels.

Users of art materials should know that under the LHAMA law, the art material labels must show the statement, "CONFORMS TO ASTM D-4236." This statement indicates that the art material has been reviewed for toxicity by a qualified toxicologist. Currently, under the LHAMA law, expiration dates of toxicological reviews are not required to be listed on the art material packages. To be safe, people buying art materials should ask sellers if the toxicological review conducted on the art materials is still valid and has not expired after percentage of young the percentage of young individuals (14-15 years old) who use art materials. Eighty percent of the children in the survey use these materials but only $30 \%$ of those read the labels. Thirty-five percent have some knowledge that these art materials may contain harmful chemicals and $12.5 \%$ of those who know the risks also read labels. These data suggest that there are a large number of people (64\%) who, even though they know that art materials may contain harmful chemicals, do not read labels.

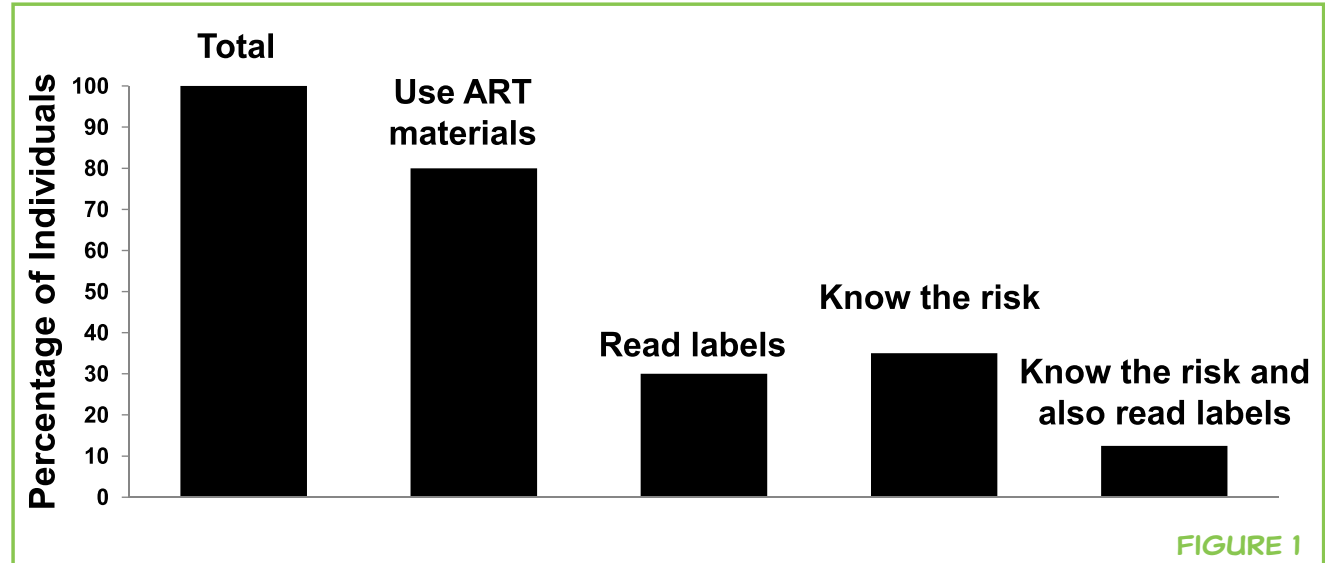


the 5-year period. Art materials for which the toxicological review has already expired or is suspected to be expired should not be used.

Children should be informed about the risks of art materials. If the children are too young or are physically/mentally challenged, they should be supervised and assisted by individuals who are well informed about the risks of the art materials.

\section{CONCLUSION}

Some art materials can contain multiple toxic chemicals with the ability to damage DNA and/or other cellular machinery. The harmful impact of these chemicals can be greatly increased by their interaction with each other, with the environment, or in people with certain genetic disorders (especially those affecting DNA repair) or lifestyle factors (such as smoking) that pose similar risks. Therefore, long-term or irresponsible use of these materials poses a serious health risk. The risk is greater for children, seniors, and mentally and/or physically challenged individuals. Although there are laws and regulations that ensure protection from the potential harmful effects of art materials, the risk can be further reduced by (1) changing the law to make it necessary to put the toxicological review date on the labels of art material; (2) educating children, elementary school teachers, and adults who help or assist these children; and (3) educating all those who are involved in the use of art materials about the importance of reading labels.

\section{REFERENCES}

1. Shammas, M. A., Rajput, S. A., Ahmad, D., Ahmed, M., Mustafa, Z., and Ahmad, G. 2016. Inclusion of "toxicological review expiry dates" in art material labels may further reduce the risk of chronic toxicity, including that of cancer. Front. Oncol. 6:4. doi:10.3389/fonc.2016.00004

2. Shammas, M. A., Shmookler Reis, R. J., Koley, H., and Munshi, N. C. 2008. Dysfunctional homologous recombination mediates genomic instability and progression in myeloma. Blood 113(10):2290-7. doi:10.1182/ blood-2007-05-089193

3. Tchounwou, P., Yedjou, C., Patlolla, A., and Sutton, D. 2012. Heavy metals toxicity and the environment. EXS 101:133-64. doi:10.1007/978-3-7643-8340-4_6

4. Shammas, M. A. 2011. Telomeres, life-style, cancer and aging. Curr. Opin. Clin. Nutr. Metab. Care 14(1):28-34. doi:10.1097/MCO.0b013e32834121b1

5. Miller, B. A., and Blair, A. 1992. Cancer risks among artists. Leonardo 25(2):169-73. doi:10.2307/1575708

6. US Consumer Product Safety Commission's (CPSC). Regulation in 16 CFR 1500.14(b) 8 \{Labeling of the Hazardous Art Materials Act (LHAMA)\} for "Chronic Toxicity". 
SUBMITTED: 28 August 2016; ACCEPTED: 22 February 2017;

PUBLISHED ONLINE: 14 March 2017.

EDITED BY: Fulvio D'Acquisto, Queen Mary University of London, UK

CITATION: Shammas MA, Shammas H, Rajput SA, Ahmad D and Ahmad G (2017) Art Materials Can be Dangerous! How Can You Reduce Your Risk? Front. Young Minds 5:6. doi:10.3389/frym.2017.00006

CONFLICT OF INTEREST STATEMENT: The authors declare that the research was conducted in the absence of any commercial or financial relationships that could be construed as a potential conflict of interest.

COPYRIGHT (c) 2017 Shammas, Shammas, Rajput, Ahmad and Ahmad. This is an open-access article distributed under the terms of the Creative Commons Attribution License (CC BY). The use, distribution and reproduction in other forums is permitted, provided the original author(s) or licensor are credited and that the original publication in this journal is cited, in accordance with accepted academic practice. No use, distribution or reproduction is permitted which does not comply with these terms.

\section{REVIEWED BY}

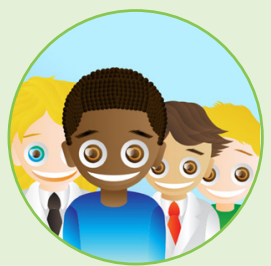

\section{ALANI, 9 YEARS OLD}

I was born in the summer months and am very active in different sports. I have been running since I was 5 . I am in swimming team, play basketball, and currently play trombone. I love to watch TV and I am the oldest of four girls. When I grow up I want to be a pediatrician and own a practice with my sisters:-

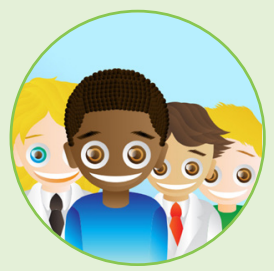

\section{ALEAH, 8 YEARS OLD}

I am a winter baby and extremely family oriented. I love doing things involving family members. I am active in sports and been running since I was 5 and basketball. I used to play piano. I am in technology club at school because I love things involving technology and computers. I am the 2nd oldest of four and referred as "mommy" sometimes as I am always taking care of my younger sibilings. I am an awesome big sister, smart and love to read. When I get older I want to become a pediatrician and own a practice with my sisters.

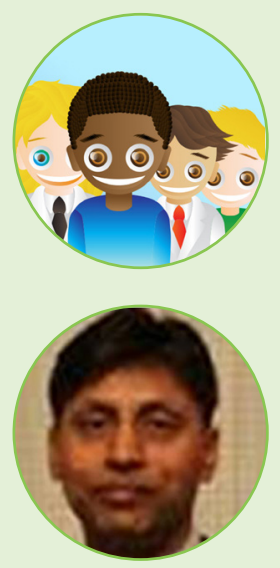

MATHEW, 11 YEARS OLD

Living in Tulsa with mom, dad, a brother in college and a sister. I love science.

\section{AUTHORS}

\section{MASOOD A. SHAMMAS}

Dr. Shammas is employed as a Lead Scientist in the field of Translational Cancer Research at Harvard (Dana Farber) Cancer Institute, Boston, USA. His research focuses on understanding mechanisms underlying genomic instability and their translational significance in cancer. $\mathrm{He}$ is a co-author of around 50 scientific publications including book chapters and has trained a number of students (undergraduate, graduate), postdoctoral fellows and 


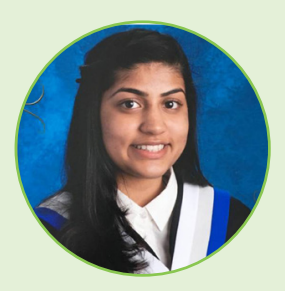

clinical fellows. He has served as Principal Investigator, Co-Principal Investigator, and/or Co-investigator on several research grants from the $\mathrm{NIH}$ (USA). He has served and/or still serving as editor/guest editor for several scientific journals, scientific manuscript reviewer for national, and international scientific journals, scientific grant reviewer for international funding agencies, and as an external examiner for Ph.D. students in universities abroad. *masood_shammas@dfci.harvard.edu,masood.shammas@gmail.com

\section{HIRA SHAMMAS}

Hira is a student in grade nine at Bur Oak Secondary School, Markham, ON, Canada. She was born in Boston, MA, USA. Her goal is to help as many people as possible, therefore, she wants to become a physician and a scientist. In this article, Hira tried to find out the percentage of young individuals who know that ingredients in art materials may contain harmful chemicals. She also tried to find out how many people read labels on such products. She assisted in designing a questionnaire, which she subsequently used to interview students. After generating the data, she analyzed and presented the information as a bar graph in the manuscript.

\section{SAMIYAH A. RAJPUT}

Samiyah is a graduate of California State University of San Bernardino with her B.S. in Biology. She has completed internships with Organizations such as Dana Farber Cancer Institute in Boston, MA, as well as volunteering her time to programs that contribute to environmental causes. She currently works as Assistant Microbiologist for an Environmental Testing Lab located in Southern CA.

\section{DILDAR RAJPUT AHMAD}

Dr. Ahmad is a scientist and expert in the field of Clinical Toxicology and Pharmacogenomics with several authorships and publications regarding human health and safety. After completing his medical degree, he trained at the Los Angeles County Department of Public health laboratory and since then has set up and directed many clinical therapeutic and illicit drug monitoring and addiction recovery programs nationally. He has also served on many county administrative boards such as Substance Abuse and Prevention Program, Riverside County and currently as Commissioner Department of Mental Health, Riverside County. He has also been instrumental in establishing personalized medicine and Pharmacogenomic programs at many medical institutions, clinics, and physicians offices. He is scientific advisor to the Medical Cannabis industry and sits on the advisory board of Kushy Punch and Pharmazam.

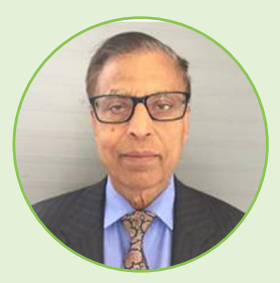

\section{GULZAR R. AHMAD}

Dr. Ahmad completed his Postdoctoral training in the field of Developmental Biology and Toxicology at UCLA, Brain Research Institute. He is an author of several scientific articles and holds various certifications in the field of toxicology, environmental, and Occupational health, which include DABT, CIH, ERT, CSAC, and CHMM. Dr. Ahmad's main interest of study is in field of toxicology with special focus on cancer and reproductive toxicity. At the present, Dr. Ahmad is serving as a Senior Toxicologist and President of "InfoTox International, Inc", Riverside, CA, USA. 